\title{
CHINA AND ITS INTERESTS IN LATIN AMERICA
}

\section{CHINA Y SUS INTERESES EN AMÉRICA LATINA}

Bryan J. Naranjo-Navas ${ }^{1}$ Christian P. Naranjo-Navas ${ }^{2}$

\section{Abstract}

It is a reflection article based on a bibliographic review. Its objective is to analyze the Chinese political and economic interest in Latin America, especially, to examine Chinese investments in the strategic sectors in Venezuela, Brazil, Argentina, and Ecuador. The article reaches three conclusions that help to understand this influence: first, the influence of China was possible by the political withdrawal of the governments of the United States; second, China's growing need to supply its raw material industries; and third, the generation of debtors that would be linked to China for many years, in some cases, the payments were scheduled to finish in a couple of decades. Within these elements, China's influence over the region has developed, increased, and strengthened.

\section{Key Words}

China, Latin America, Economy, Politics.

\section{Resumen}

Este es un artículo de reflexión basado en una revisión bibliográfica, y cuyo objetivo es analizar el interés político y económico chino en América Latina, especialmente, examinar las inversiones chinas en los sectores estratégicos en Venezuela, Brasil, Argentina y Ecuador. El artículo llega a tres conclusiones que ayudan a comprender esta influencia: primera, la influencia de China fue posible por el retiro político de los gobiernos de los Estados Unidos; segunda, la creciente necesidad de China de suministrar a sus industrias de materias primas; $y$, tercera, la generación de deudores que estarían vinculados a China por muchos años, en algunos casos, los pagos se programaron para finalizar en un par de décadas. Dentro de estos elementos, la influencia china sobre la región se ha desarrollado, aumentado y fortalecido.

\section{Palabras clave}

China, América Latina, Economía, Política.

\footnotetext{
${ }^{1}$ Universidad San Francisco de Quito (Ecuador). Correo electrónico: eldestinobryn@hotmail.com.

${ }^{2}$ Universidad Nacional de Chimborazo (Ecuador). Correo electrónico: cnaranjo@unach.edu.ec.
} 


\section{Introduction}

The last decades of the twentieth century did not bring the announced prosperity by the democratic discourse of the west. The multiple political and economic crises opened the doors to consider other types of governance. It is understood that from the beginning of the twentieth century, a new political movement became very popular in Latin America. This movement was called Socialism of the XXI Century. These movements arrived in power through political elections.

Nonetheless, once in power, most of new presidents organized national assemblies to construct new constitutions. These new macro-legal systems provided the presidents with extensive power to influence the judiciary and parliamentary power. While at the same time, built strong control organizations and methods over the press and private businesses. The new socialist movements made use of elections to justify the changes that occurred in the rest of the political and economic structure.

At the same time, China had become one of the superpowers of the world. This phenomenon started in the decade of the seventies. Before that, China experienced one of the biggest catastrophes of the twentieth century, thanks to poverty and starvation, which were caused by a very controlled and centralized economy. Since the changing of direction in 1979, China became a free-market-oriented economy, with an annual growth average of $9.5 \%$ in the last four decades, becoming one of the fastest-growing economies (Morrison, 2018). This growth rate made it possible to duplicate the Gross Domestic Product, GDP, every decade and led 800 million people out of poverty.

In recent decades, China's influence on the development of the world's economy has not stopped growing and been accentuated even more after the financial crisis of the world in 2008. After 2008, China has entered with a peculiar strength into negotiations with the developing nations of the world. Especially with the Latin American countries which have faced the increment of oil prices, many countries from South America entered into external debt to pay the rise of public expenditure, expecting oil prices to stay high for a long time. While in 2000 , the Asian giant represented about $3.6 \%$ of world GDP, in 2016, its share amounted to 15\% (Villafañe, 2016). By 2016, China was already the largest industrial and agricultural producer in the world.

The growth of a new superpower found a big need for raw materials that were to be found around the world. In this sense, China found a necessity to combine its growth with strategic associations. The bilateral association, thanks to the tremendous Chinese demand for raw materials, which triggered the international prices, was the main factor in the region's growth. Latin America encountered a potent partner. China was open to paying high prices for raw material from the region to get in return the availability of building and managing the most important infrastructure, mining, oil, and electric businesses.

The talks among the Latin American and China leaders included some political and economic aspects of mutual interests, especially the negotiations of the handling of the strategic segments. When the raw material touched its price pick in 2014, the promptness of the negotiations with China slowed down as the governmental budget of the developing countries went through a prolonged stagnation; the worth of the commercial exchange between Latin America and China reduced for three consecutive years. However, in 2017 the price of Latin American exports increased to 25\% (Ray and Gallagher, 2015), after a slight fall, it continued rising until 2018 (Index Mundi, 2019). The same source shows that the index of fuel commodities grew 46 points from February 2016 to October 2018. While the metal price index grew 30 points in the same period, the food price index only grew 10 points, and the agricultural raw material grew 3 points. After 2017, the prices of raw material recovered as a partnership with the developing nations. Nonetheless, the partnership was not the same as before, as the political scene of the Latin American countries started questioning the benefits and costs of the partnership with China.

Despite the strong growth driven by the increase in oil and certain raw materials prices, the commercial exchange with China is still in a severe growing tendency. According to the Economic Commission for Latin America and the Caribbean, ECLAC, 10\% of the region's exports of goods in 2017 were destined for China, while $19 \%$ of imports came from there (Villavicencio, 2013). It is predicted that in less than a decade, the Asian country will displace the European Union as the second-largest buyer of Latin American products behind the United States, which in 2010 had already yielded the first place as the main exporter to Latin America.

The Chinese phenomenon happened at the same time as the United States, before completing the second year of Trump administration in the White House, decided to start a commercial battle by imposing import tariffs on Chinese products. The US Government decided to retreat from the international agreements, questioning alliances and breaking treaties. In Latin America, China became an important political and economic partner of the region. 
With the Socialism of the XXI century movements, it had not only economic interests in Latin America, but also political interests. The Asian tiger found the perfect political context to spread its political, cultural, and social power and to fill the space that the US left with the governments. The withdrawal from the region began with Obama's government, which allowed the region's socialist government to develop. After Obama, Trump established his devotion to the anti-globalization program of "First America"; nonetheless, the new US president rapidly got involved in the Venezuela crisis and the support to the new right-wing governments in Brazil, Chile, and Colombia.

Given the relative increase in China's investment and influence and the decreasing influence of the United States, the Latin American countries have encountered the need to revise the consequences of these commercial and political relationships, in order to make better decisions. In this sense, this article analyses recent research results of China's interests in Latin America, from a political and economic perspective. This reflection article, which bases its conclusions in a bibliographic revision, intends to analyze the Chinese political and economic interest in Latina America, whose main purpose is to focus on the Chinese investment in the strategic sectors in Venezuela, Brazil, and Argentina, and Ecuador.

\section{Political and economic context}

In the last decades, China's influence on the development of the world economy has not stopped growing. It has been accentuated in the last decades, especially with the arrival of some leftist Latin America leaders, such as Hugo Chávez in Venezuela, Lula da Silva in Brazil, Nestor Kirchner and Cristina Fernandez de Kirchner in Argentina, and Rafael Correa in Ecuador. This new political movement created the image of the enemy incarnated in the United States, and in any political link that could be tracked to the hegemon. At the same time, the government of Barack Obama started a policy of no intervention: the no intervention built the perfect political context through which China entered as the new ally of the region.

The policy of no intervention continued rhetorically within the campaign of Donald Trump; however, once in power, the U.S. tried to regain the lost political and economic space with political candidates and new presidents that eventually replaced the socialist government structures. Leaders such as Mauricio Macri in Argentina, Jair Bolsonaro in Brazil, and Sebastian Piñera in Chile and there was an endless diplomatic and economic campaign to get Nicolas Maduro out of the autocratic Venezuelan regime. The United States Government faced contradictory rhetoric of protecting the national boundaries and retreating from the international commercial agreements and, at the same time, trying to recover the political space lost during the Obama administration.

In Latin America, China, which has been an important trading partner for more than two decades, increased its political, cultural, and social influence to fill the gap created by the lack of a U.S. diplomatic strategy. In less than a year, the U.S. president had confirmed his loyalty to his anti-globalization agenda of "First America." Trump has withdrawn the U.S. from the Trans-Pacific Partnership (TPP) with Asian and Latin American countries and the Paris Agreement, to which all the nations of the world are subscribed. The U.S. President threatened to end the Free Trade Agreement (NAFTA) with Mexico and Canada, obligating these countries to sign a new agreement. The United States-Mexico-Canada Agreement (USMCA) in which the protection for U.S. intellectual property, digital trade, anticorruption, food, and agriculture trade is emphasized (Office of the United States Trade Representative, 2019). This agreement was a political victory for the Trump administration, which in rhetoric kept the slogan of "America First", but in practice, it tried to recover a new influence in the international arena. "I will always put America first; we cannot continue participating in agreements in which the United States does not get anything good" (NBC News, 2017), said the Republican president at the U.N. General Assembly.

During the government of Barack Obama, the XXI Century Socialism found some strategic partners in Russia and China. From both countries, the main association was built with Chinese investments in the region. This investment was viable in some strategic sectors, such as oil, mining, and electricity. After China lent millions of dollars in debt, forcing the Latin American governments to enter into the debt-trap diplomacy, which is a way of saddling countries with high-interest debt that they are unable to repay, giving China leverage over the borrowing countries (Dollar, 2019). The purpose was to lend money to developing countries to construct infrastructure in transport, power, water supply, and other sectors, in 2017. President Xi Jinping noted that China needs to seize opportunities presented by the new round of change in the energy mix and the revolution of energy technologies to develop global interconnection, achieve green and low-carbon development, improve trans-regional logistics network, promote connectivity of policies, rules, and standards to provide institutional safeguards for enhancing connectivity (Xinhua, 2017). 
According to Gallagher and Myers (2020), from the InterAmerican Dialogue, Latin America has 84 loans from China, amounted to a total of USD 137 billion. From the total, there are 34 loans for energy (USD 91,9 billion), 34 for infrastructure (USD 26,8 billion), 3 for mining (USD 2,1 billion), and 23 for other types of investments like government bonds, trade financing, home construction and financing funds in Venezuela, satellite development in Bolivia and business development in Uruguay (USD 16,2 billion). In Brazil, Ecuador, and Venezuela, China signed quasi-collateralized loans with the option to pay in oil.

Some of these loans have been used to finance debt. This massive amount of loans creates the threat of falling into the debt-trap, which can be unfolded through the administration of strategic sectors such as energy or the repayment in oil or mining material. The risk of falling into the debt-trap is more real, considering that the oil prices collapsed in 2020, registering negative prices in April. The fall of oil prices has been constant from 2013, from USD 90 per barrel $(2010=100)$ to USD 54 in 2019 (The World Bank, 2020). For oil producers such as Brazil, Venezuela, and Ecuador, the little income from the oil revenues could ensure the trespassing of the strategic sector administration to the Chinese companies.

Despite the large number of resources coming from China, capitals were not invested in making the economy sustainable, so that the revolutionary movements' apparent rhetoric could be real. Vilar (2018) believes that the economic resources that came from China from the commerce of raw materials were wasted in the propaganda of the governments, rather than in the creation of an essential emerging middle class that would ensure, its consumption, and the economic mobility of their countries.

According to Vidal Molina (2019), after the economic crisis of 2008, a critical development began to expand, both from academic, political-institutional, and social movements, to find a solution to the new problems that the world and, especially, the Latin American region were facing. Before this crisis, since the end of the 1990s and in the early 2000s, social processes in some Latin American countries showed signs of a critical situation based on the implementation of neoliberal policies. These signs gave space for the rebuilding of a new political hegemony that was encompassed around the idea of new socialism. The elected leaders of this new socialist movement found strategic partners in nations with a socialistic historical background such as China and Russia.

The financial crisis of the world opened the eyes of the region to a new important partnership in powerful nations. While in the year 2000, the Asian giant represented about $3.6 \%$ of world GDP, in 2016, its share amounted to $15 \%$. China was already the largest industrial and agricultural producer in the world. The bilateral agreements that were signed, thanks to the great Chinese demand for raw materials that triggered the rise of prices, were the main factors of growth for the region. According to López Villafañe (2016), the Chinese model has been based fundamentally on cheap labor, which represented two economic problems, at least for this country. For a large majority of Chinese workers, their labor is still cheap; that is, their wages have not increased at the same rate as prices. It leads to the problem of China's future economic sustainability. The other problem arises in the objective of industrial and technological; nonetheless, the instruments for this massive change are in the hands of the Chinese companies, which remain competitive in the old, low-qualified branches characterized by low innovation and technological development. This situation could change with the Made in China 2025 plan, which tries to develop rapidly artificial intelligence, communications, air navigation, robotics, biotechnology, electronics, among others.

Ray and Gallagher (2015), in their annual China-Latin America bulletin, analyzed the China greenfield projects, the larger one was the Nicaragua Canal, larger than all other Chinese greenfield FDI projects for the last five years combined. Even though the planned canal never started, Ray and Gallagher also mentioned that China registered $17 \%$ of new greenfield projects in Latin America, more than any other year. During the first decades of the twentieth century, the Chinese investment focused on extraction projects with the oil and gas sector accounting for 69\% of Chinese investment between 2009 and 2013.

After this glorious commercial relation, during the reduction of oil prices in 2013, the economy of the developing countries stopped its growth. The value of the commercial exchange between Latin America and China was reduced for three consecutive years. However, in 2017 the value of Latin American exports increased strongly to $25 \%$, approaching the highest level reached in 2013 (Ray and Gallagher, 2015). The commercial relations between Latin America and China would not be the same since the region's political environment had changed: many of the socialist leaders of the region were changed democratically. Although the Chinese influenced diminished since 2017, its investments over the last two decades were so profound that, after the COV19 crisis, the partnership will continue with new possible outcomes as some countries might decide to sell or cede the administration of their emblematic investments. 
With the arrival of new Latin American governments, which made clear differences with the socialist movements of the first decade of the twentieth century, the agreements with China became a critical aspect of the local politics. The agreements were made within a capsule of hermeticism; however, some journalists had few courageous efforts to visualize some of the axes of the commercial agreements with China. Fernando Villavicencio (2013) published a comprehensive book on the political and economic repercussions of the commercial agreements between Ecuador and China. Villavicencio stated that the heart of the Ecuadorian model was the return to an expanded extractive mechanism of development that combines oil exploitation, mining exploitation, global toll, export agriculture, biofuel, environmental services, and the excessive growth of speculation in various sectors of the economy.

According to Villavicencio, several of the commercial agreements with China were linked to the payment of oil credits (prepayments), around USD 3 billion, with interest ranging between $6 \%$ and $7.25 \%$ per annum. Besides, they served as collateral, cover, and down payment for other credits, such as the USD 2 billion agreed in 2011. In total, the commitments with Petrochina added up to more than 421 million barrels of oil in long-term contracts.

Despite the change of the local political scenario, China's influence in the region continues. According to ECLAC data, $10 \%$ of the region's exports of goods go to China, while in 2017, 19\% of imports came from the Asian country (Villavivencio, 2013). In this way, soon, China will displace the European Union as the second-largest buyer of Latin American products behind the United States, which in 2010 had already yielded the first place as the main exporter to Latin America. In absolute values, commercial relations show that China already displaced the European Union. It did not happen with the U.S., which remains the first regional commercial partner, showing that the U.S. retreat from the region was more a political than an economic one.

\section{China's influence in regional politics}

China has shown that it has a well-defined long-term strategy of where it wants to go and what it expects from Latin America. On the other side, Latin America never showed a clear political strategy more than follow the political rhetoric against imperialism. From the beginning of the socialist Latin American governments, the partnership with China arose as a natural link which unfolded in trade, assistance, and cooperation in energy endeavors, used diplomatic approaches to support the Latin American political discourse, and sought natural resources as payments of investments. In sum, Latin America provided a big portion of raw materials and money for the growth of China.

Lafargue \& Lafargue (2017) remarks that China had no interest in Latin America during most of the twentieth century due to the overwhelming presence of the United States in the region. Nonetheless, from the beginning of the twenty-first century, this passivity changed, beginning with a growing presence in Brazil, Argentina, and Chile. China's investments have pushed away from the United States' diminishing influence, considering the withdrawal of the governments of Barack Obama. Although China's influence over the region is undeniable, it has proven to be an untrustworthy partner. In fact, China did not doubt to vote against Brazil when the later tried to ensure a U.N. Security Council seat in 2018.

Domínguez Martín (2017) has argued extensively that China's influence over Latin America politics is a cornerstone of preoccupation for the United States because its image has been changing in the region, from a powerful partner to an authoritative, hegemonic, allpowerful evil. While the image of the United States is negative, the image of China has remained neutral, with few spots of political discourses against the Asian power, but, overall, with a hidden image. These variants have restructured the political game having the United States as the all-powerful, authoritative, hegemonic evil partner on one side, and China, very distant to be important, as the neutral partner on the other side. This important aspect of the region's international relations is especially evident with Mexico, Argentina, Chile, Ecuador, and Brazil. Although the problem of a decreasing political relationship among the United States and Latin America is real, Domínguez Martín thinks that it is doubtful that the U.S. influence will degrade more in the next years.

Similar studies have been done by Johnson (2017), who has argued that the U.S. government's underestimation of the Chinese influence has opened the door to worry since the U.S. image in the region has deteriorated rapidly in the last decades. President Trump's administration released the National Security Strategy in 2017, stating that China expanded its power at the expense of the sovereignty of other countries while seeking to displace the United States in the Indo-Pacific region, expanding the programs on a state-driven economic model. The national security strategy comes as a response to the China's Policy Paper on Latin America and the Caribbean (Xinhua, 2016) which stated the goal of establishing a comprehensive and cooperative partnership featuring equality, mutual benefit and common development with Latin American and Caribbean countries while 
supporting the ideological political forums such as the Community of Latin American and Caribbean States, CELAC. The White House of Donald Trump initiated a discourse that blamed socialism for the devastation of countries such as Venezuela and Cuba.

Some scholars used the term Beijing Consensus to refer to several fundamental features within of the economicpolitical relation for development. The first feature was based on a constant commitment to innovation and experimentation. The second feature was the non-fixation of per capita GDP growth as the ultimate goal of the development model, but the promotion of a sustainable and equal development model. With this image, China has been seen as a mixture of a threat and a blessing in the region. On the one hand, it has increased imports of raw materials, causing bilateral trade balances with surpluses in economies such as Chile and Peru, a surplus that has been accentuated by the increase in the price level of minerals during the twentieth-first century. For instance, the price of the metric ton of copper rose rapidly from the 1998 crisis, from USD 1572 to USD 8828 in 2011 (The World Bank, 2020). The copper price fall was not similar to oil; the average copper price remained stable at around USD 6000 until 2019.

Although China did not offer a clear discourse in support of Latin America's socialist governments during their time in power, after the new model of governance came to the region, China's officials stated repeated letters in support of the remaining socialist governments, especially to Venezuela. In 2015, CELAC, an organization made up of 33 American countries, rejected the first sanctions, joining the Group of $77+$ China, which issued a similar statement. In 2017, China joined those who condemn U.S. warmongering rhetoric against Venezuela, reminding President Trump of the principle of noninterference in other countries, "all countries should conduct their bilateral relations based on equality, mutual respect, and non-interference in each other's internal affairs." (HispanTv, 2017) In 2019, China supported the Venezuelan government's efforts to maintain sovereignty, independence, and national stability (Tamara, 2019). In 2020, the Chinese Foreign Ministry spokeswoman Hua Chunying reiterated China's support for the independence and sovereignty of the Bolivarian Republic of Venezuela against the intention of changing the government of Maduro by a democratic president. Hua Chunying stated that "Venezuela is an independent and sovereign State, China has constantly opposed the violation of Venezuela's sovereignty and any external interference in the country's internal affairs, we also oppose the illegal unilateral sanctions." (TeleSur, 2020).
China has been more politically active in the region. However, Latin America is not a priority for China, since it is located in a less important place than the United States, Asia, or Europe (Cornejo \& Navarro, 2010). From a political point of view, Latin America is essential for China in a diplomatic dispute with Taiwan. After decades of hostility, relations between China and Taiwan started improving from the 1980s. The Chinese proposal of unification was rejected, even the plan known as "one country, two systems," in which Taiwan would be given significant autonomy if it accepted Chinese reunification (BBC News, 2019). In 2018, China pressured international companies to enlist Taiwan as a part of China, threatening to block any doing relations.

There is disagreement on how to consider Taiwan since it has its own constitution with democratically elected leaders and about 300,000 active troops. China's political influence in the region has a strong arm in the economic ties with Latin America. Blanchard (2019) has argued that the growing economic dependence of Latin American economies has come hand in hand with the extensive political influence of the Asian tiger in the region. The author believes China is not only looking for its economic development but also its political influence in a region dominated by the United States. The political ties come along with the economic one having in mind that China is playing an important role in Latin America for their own political and economic reasons: the intention of setting aside the U.S. influence; the political pressure to not recognize Taiwan or the Tibet as independent regions; and, the assurance of the flow and administration of raw materials from Latin America.

\section{China impact of Latin America economies}

Gallagher K. (2016) has researched the impact of China in Latin America, affirming that the main element between both partners is trading, in fact, China has become the main export destination for countries such as Brazil, Chile, and Peru, and has become the second country of export destination for Argentina, Costa Rica, and Cuba. This fact has engaged China with the regional decisionmaking process that has produced many bilateral agreements.

China has ensured the supply of raw materials for the next decade. This type of strategy came through the hand of debt; the Latin American countries got into increasing amounts of debt, much of which will be paid through the exports of raw materials, primarily through the commerce of oil. The bilateral commercial relations have been contextualized within the trade of commodities 
and, in return, the availability of debt or investments. Gil Barragán \& Aguilera Castillo (2017) believe that China has played a double role in the region. On one side, China has become the most important commercial partner by incrementing foreign direct investment; on the other side, China has become a competitor to the manufacturing areas. This type of commercial relationships have structured the outcomes in four possible ways: first, the Chinese demand of raw materials has created a weak position for Latin America due to price fluctuations; second, the Chinese investments have pushed countries to a mutation of production; third, the manufacturing sector of the region is on risk due to the competitive Chinese sectors that have been implemented in oil and mine industries; fourth, China has a growing market share on the manufacturing sector, affecting the exports of the Latin American countries.

Johnson (2017) mentions that the chain benefits from the continued movement of natural resources from Latin America to China propose a big challenge for the U.S. economic influence in the region. While the U.S. figures out a proper way to create an international image, China's influence has created a growing dependency in Latin America: a good part of the living standards of the region depends on the inflow of economic resources from China. Likewise, Hiratuka (2018) affirms that, during the first decade of the twenty-first century, the Chinese economic flows are remarkable in foreign direct investment, financing flows, and infrastructure projects. These factors propose a new platform that is more important than trade alone, "post-crisis changes have caused the growth rate of exports to decrease due to the fall in commodity prices and the slowdown in the Chinese economy's growth. However, the accumulation of idle capacity and the stagnation of world demand mean that imports from China continued to increase to be only interrupted by the sharp slowdown in LA economies more recently" (2018: 20).

The ties between China and Latin America has two faces which have developed two challenges, one for the region and one for the United States. The challenge for the region is clear when we consider the topic of dependency and the region's challenge to face a growing dependency on China in three areas: trade, infrastructure, and foreign direct investment. This dependency became clear in the 2020 economic crisis. On the other hand, the U.S. challenge shows the impossibility of a clear strategy towards the Latin America region when the socialist movements are very active: the general strikes in Latin America at the end of 2019 showed the political and logistic power of some socialist groups. These challenges propose a new scenario of the region's future and its coming political and economic tests.

Also, as seen in figure 1, Perroti (2015) states that the Chinese demand for Latin American primary products has emanated from its industrialization process, in which metals have played a preponderant role. The dynamism of this process has not only led to increases in the quantities demanded but has also caused significant upward pressure on the prices of primary and mineral goods, which translated into a substantial improvement in terms of trade in many Latin American countries. According to the work of Jenkins (2011), the "Chinese effect" on world demand has had an impact on minerals and metals because China has reached an income level in the use of metals in relation to GDP. It has been a consequence of the country's rapid industrialization process. The demand for metals has also been boosted by construction and other infrastructure projects.

Figure 1. The impact of the Chinese demand on world prices, in percentages, 2007

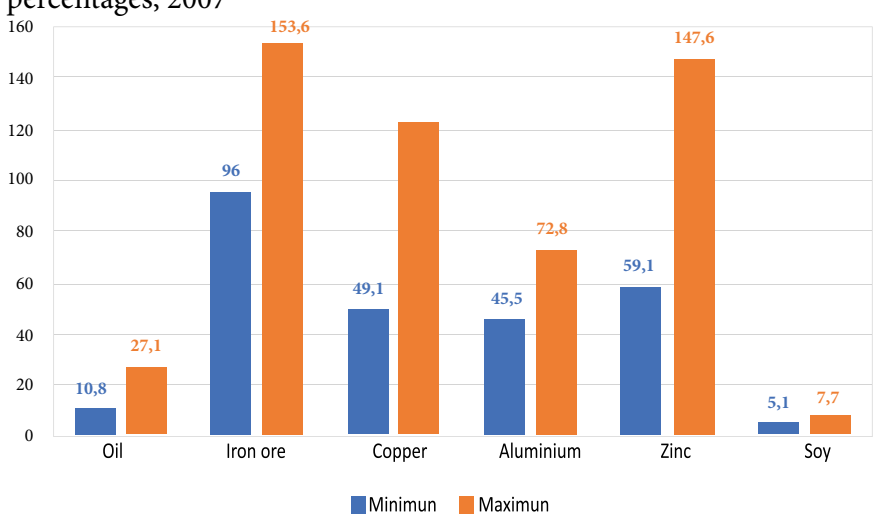

Source: Perroti, 2015, p. 50.

China is leading the primary sector consumption as a generator of manufacturing, which is mixed with the added value and technological improvements. There have also been significant advances in the service sector in which the Asian country has increased its efficiency, especially in the services related to trading (transport, physical infrastructure, communications, business, and professional services, including financial services).

The role of this economy as a global consumer is also substantive: China buys $53 \%$ of foreign sales of soybeans, $28 \%$ of soybean oil, and $23 \%$ of cotton while occupying the first place as a global consumer of coal, tin, zinc, and copper (Perroti, 2015). Concerning the latter, its participation in the world consumption of minerals and metals was around $40 \%$ in 2009 in lead, nickel, tin, zinc, primary steel, refined copper, and aluminum. That same year, it consumed $10 \%$ of crude oil worldwide. 


\section{China's investment in Latin America}

According to Ortiz (2017), since 2010, the average flow of foreign direct investment to the region has been close to USD 172,000 million. Twice the average flow received between 2001-2009, but with an accumulated fall of $26.6 \%$ between 2011 and 2016. In this context, the estimated Chinese foreign direct investment went from an average annual amount of USD 1,357 million between 2001-2009 to USD 10,817 million in 2010-2016. The Chinese foreign direct investment reached its third-highest level in 2016.

During 2001-2016, Chinese companies made 274 transactions with the region's countries, with an accumulated flow of USD 87,928 million. The estimated employment associated with the investments was 202 thousand jobs. (Ortiz, 2017: 10). The period 2010-2016 witnessed the maximum dynamism for the moment, accumulating almost USD 76,000 million and 168,806 jobs. However, 7 out of 10 transactions were linked to capital increase processes during 2001-2016. New investments accounted for only $36.46 \%$ of the FDI and $49.85 \%$ of employment. In contrast, mergers and acquisitions presented an average amount per transaction five times higher than that reported by new investments and accounted for more than two-thirds of total Chinese GDP.

The data presented in this section will present and analyze the China's investments in four countries: Venezuela, Brazil, Argentina, and Ecuador. These countries have received most of the China investments if we consider only the Latin America region. The total amount of investments in these countries sum up a total of USD 126.6 billion from 2007 to 2019 in ten years, China has become the main investment partner and has become the central lender, with a total of 55 loans (Gallagher \& Myers,2020). According to the same database, the last years only registered four new loans due to the little income these countries had within the crisis produced by the fall of the commodities prices.

\section{Venezuela}

The government of Hugo Chavez tried to avoid any investment in contact with the United States. He considered the reincarnation of the devil and tried to foster deeper relationships with other governments such as the government of Russia, China, and others. Since 2007, as seen in figure 2, China has increased its investments in Venezuela, especially in two sectors: energy and infrastructure, allocating China as the main regional player that was looking for a bigger political influence in the region, especially for international topics that involve China, such as the independence of the region of Tibet. With the increment of China's influence, Venezuela lost independence and political autonomy giving the increasing amount of debt that was being acquired. Some academics calculate the external debt in USD 246 million (Trading Economics, 2019). The China investments in Venezuela has opened the door to under-the-table deals that have taken the political structure to high levels of corruption. According to the Venezuelan attorney general Tarek William Saab, Venezuela has lost USD 15 billion due to corruption (Sputnik Mundo, 2018).

China's economic investment in the region focuses on access to raw materials, making Latin America dependent on the external market. China's particular management of foreign policy to carry out a pragmatic diplomatic agenda, especially in developing countries that have essential resources, especially energy. The bilateral agreements with Venezuela cover areas such as energy, infrastructure, agriculture, technology (Rosales, Pérez, Prado, \& Bárcena, 2015). In 2019, after two decades of socialism, Venezuela had become a high-risk country for investments, including China's investments: the only way China would keep on introducing money to Venezuela is based on the acquirement of a stable source of oil and mining elements.

Figure 2. Chinese investments in Venezuela, millions of USD

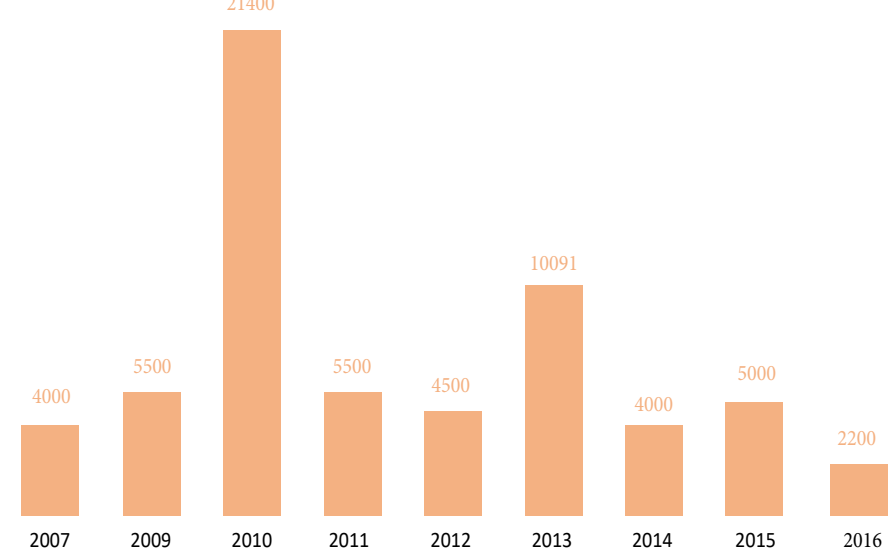

Source: appendix 1.

\section{Brazil}

Brazil is probably the main actors in the region, considering it as the main political actor, and one of the top economic actors. China's investments in Brazil coincide with Venezuela's investments: this element is understandable given the fact that socialist governments were leading Venezuela, Brazil, Argentina, and Ecuador. The government of Lula da Silva opened the doors to the strong influence and dependence on China's investments; 
nonetheless, the country's industrial apparatus was not under percussion, as it was in Venezuela. Although the country's industrial apparatus had to withhold the pressure of higher taxes and labor rights, it could keep on with the production levels.

As seen in figure 3, Brazil has received a total investment of USD 28.9 billion from 2007 to 2019. The China investments in Brazil coincided with the instability of the Brazilian economy, from the beginning of the century, Brazil's economic growth oscillated between growth and recession. In the last decades, the only period that Brazil could consider some economic growth was from 2002 to 2008, given the high levels of the prices of oil. The average annual growth of Brazil was $4.8 \%$, combined with an inflation of 6\% between 2004 and 2008 (Remes Lenicov, Viola, \& Knoll, 2015: 3). By 2019, Brazil is facing the difficult situation of balancing its finances while dancing with the political spectrum's extremes.

Figure 3. Chinese investments in Brazil, millions of USD

8000

7000

6000

5000

4000

3000

2000

1000

0

Source: appendix 2 in figure 4, China's investments in Argentina amount a total of 17.1 USD billion. During 2010-2015 foreign direct investment from China tripled, with a progressive diversification of investment projects towards the primary sector, especially energy, oil, and gas (15\%), as well as mining (19\%), and agriculture (4\%), which together account for $38 \%$ of the total (Oviedo, 2017: 101). After the government of Mauricio Macri, with the return to the socialist government of Alberto Fernandez, Argentina is facing the recovering of high levels of external debt, and high levels of social expenditures that are not supported in a coherent fiscal balance.

Figure 4. Chinese investments in Argentina, millions of USD

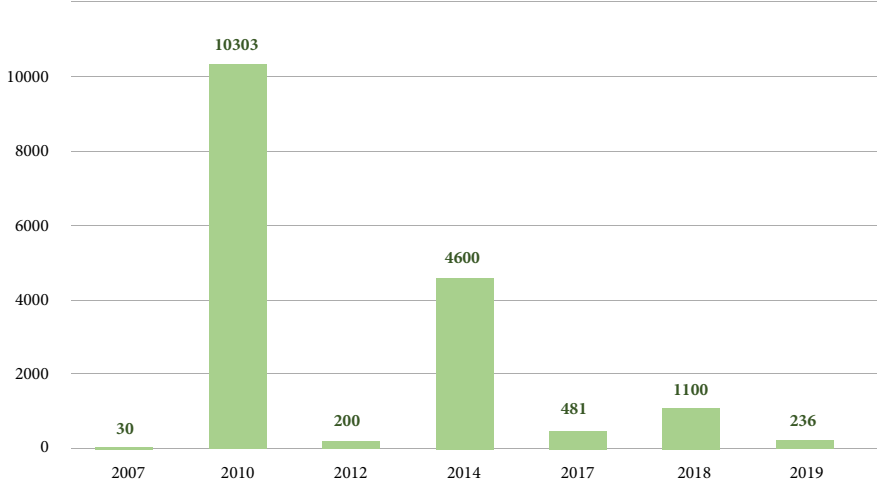

Source: appendix 3.

\section{Ecuador}

Ecuador came from a decade of a convulsionary political situation before the rise to power of Rafael Correa. Three presidents were overthrown in less than ten years. It prepared the context for a candidate's arrival that would blame all the evils of the country to the hegemon and businessmen's influence. Rafael Correa came to power with a very leftist discourse, which led the country away from the U.S. investments, in fact, away from any significant international investment until 2013, when the size of the state needed a growing amount of finances. The image of China arrived as the perfect commercial partner.

The arrival of China to the country opened the door to high levels of corruption, which is not unique to the country, but part of the regular pattern among the Latin American countries driven by the XXI century socialism. In the political discourse, the China investments came to change the industrial model of the nation, with very costly publicity campaigns that foster the idea of a new nation, with new energy sources to export it to the neighboring countries. China's investments served as a political platform to embellish the greatness of the social revolution. 
According to Luzuriaga (2017), in the context of difficult financing for Latin America, China consolidated itself as a strategic partner of Ecuador through loans with extremely lax conditions. This relation was appropriate for China's political and economic influence in the region since it allowed it to secure the necessary natural resources to position its companies on the geo-economics board. As seen in figure 5, China's investment in Ecuador amounts to a total of 18.4 USD billion, which configures China as the main creditor partner of the nation.

Figure 5. Chinese investments in Ecuador, millions of USD

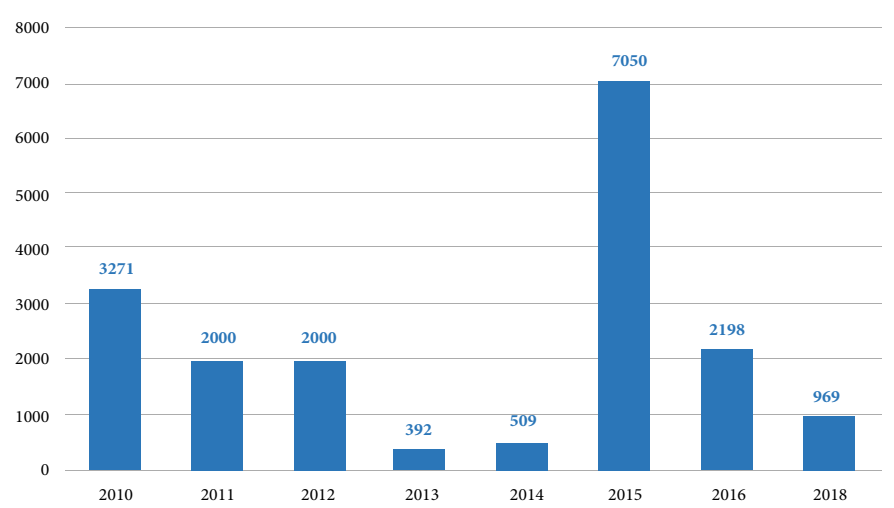

Source: appendix 4.

In the last two decades, China has passed from being a small political and economic partner of the region to be the main important one. This change of the role of China in the region has to do with two critical factors: first, the withdrawal of the U.S. as the main political influencer of the region during the governments of Barack Obama; second, the delivered intention of China to find sources of raw materials. The first element was visible during the governments of Barack Obama, who did very little to stop the increasing growth of socialism in the region and to stop the increasing inflow of China's investments. About the second point, China has played a brilliant role in offering the countries of the region large amounts of money with the condition of having the monopoly of areas such as mining, oil, and energy. With this panorama, and considering the 2020 crisis, it is likely to see China taking the administrative control of its investments in Latin America.

The China growing and bulging export of capital to Latin America since the 2000s, which has taken the form of infrastructure projects, financing, and foreign direct investment, has motivated a growing interest in the academic sector to understand their motivations, behavior, and socioeconomic and environmental repercussions. The region has also gained weight as China's trading partner. In 2000, they absorbed 3\% of
China's exports of goods and was the origin of $2 \%$ of its imports. While in 2013, its share in both flows amounted to $6 \%$ and $7 \%$, respectively. Also, around $13 \%$ of imported oil to China comes from Venezuela and Brazil. (Ríos, 2019). Despite this evolution, compared to other regions, Latin America and the Caribbean is not among the most important trading partners for China.

The bilateral trades, spurred by China's massive demand for raw materials, boosted prices, becoming the main growth factor for the region. In 2014, the economy of developing countries cooled down, and the exchange value of the region with China fell for three consecutive years. In 2017, it expanded again with significant growth, approaching the historical maximum reached in 2013; nonetheless, 2019 and 2020 paved the road to a very critical economic situation.

The countries of Latin America and the Caribbean are sources of natural resources and commodities in the global exchange. Chinese exports concentrated in Asia (50\%), the U.S. (20\%), and Europe (19\%), while the entire region represents around $6 \%$ of the total world merchandise trade. Latin America, Africa, and Oceania account for $11 \%$. Regarding China imports, 57\% corresponds to Asia, $18 \%$ to Europe, $10 \%$ to the U.S., and $15 \%$ to Latin America, Africa, and Oceania. $68 \%$ of Chinese investments were carried out in Asia, $13 \%$ in the U.S. and Europe, $12 \%$ in Latin America, $4 \%$ in Africa, and $3 \%$ in Oceania.

\section{Conclusions}

The Chinese model has been based fundamentally on cheap labor, creating two economic problems. The work of the Chinese workers is still cheap; that is, their wages have not increased enough, leading to the problem of model sustainability. Some Chinese economists call it the trap of low- and moderate-income countries, which will make it difficult for China to move to the status of a developed country. It will also limit the potential of the domestic market in the long term. Incorporating the enormous labor reserve year after year with low wages will permanently put China in the condition of being an economy of low labor cost indefinitely.

On the other hand, for a long time, China's position as a pivotal partner to Latin America has been underestimated, mostly limiting it to a growing and significant role in trade and investment but underestimating its political role. The accelerated path of the preceding years was complemented by the signing of widespread strategic partnership agreements with the socialist governments of 
Argentina, Brazil, Ecuador, and Venezuela.

Latin America is part of China's future objectives. China represents an opportunity for the region to improve infrastructure, productive capacity, and the formation of technical cadres, including the development of an economy more attentive to the environment and improving connectivity and governance. China was perceived as an actor that helped improve stability in the region until the withdrawal of some socialist governments. After the oil price reduction and the change of governments, China's image has grown in the persistence of doubts and reservations of its intentions.

As shown in this research, the influence of China has increased in the last two decades due to three crucial elements. First, the last U.S. executive administrations played an essential role by deciding to step away from regional politics. It was understandable to have foreseen the rise of socialist movements that were guided by the political and economic models of Cuba and Venezuela. These regimes tried to depart from any association with the U.S. and start new relations with other countries, especially China, the most rapidly growing power in the last decades.

Second, the China interest in ensuring the supply of raw materials. This element is especially evident when China's investments were considered. China's investments can be divided into three areas: oil, mining, and electricity. The first two areas are significant to assure a growing industry and a growing China economy.

Finally, China's political strategy in the region: China has assured its influence in the region for, at least, another decade, given the type of debt contracts that the Latin American countries signed. Countries such as Venezuela, Bolivia, Ecuador, Nicaragua, Argentina, and Brazil got into debts with China with repayments that were agreed to be done with oil exportations. In some cases, these repayments were programmed to finish in a 5-10-year period.

\section{References}

1. BBC News. (2 de January de 2019). What's behind the China-Taiwan divide? Recuperado el 4 de mayo de 2020, de https://www.bbc.com/news/worldasia-34729538

2. Blanchard, J.F. (2019). The Politics of Latin America's Investment and Other Links with China:
Contextualizing the Region's Cash Chasing while Racking Richer Research Rewards. Journal of Chinese Political Science, 24(4), 565-582.

3. Cornejo, R. \& Navarro, A. (2010). China y América Latina: recursos, mercados y poder global. Nueva Sociedad (228), 79-99.

4. Dollar, D. (2019). Understanding China's Belt and Road Infrastructure Projects in Africa. Brookings Institution.

5. Domínguez Martín, R. (2017). La Princesa y el Dragón: Cooperación China en América Latina y más allá. Revista Internacional de Cooperación y Desarrollo, 4(2), 3-27.

6. Gallagher, K. (2016). The China Triangle. Latin America's China Boom and the Fate of the Washington Consensus. Oxford: Oxford University Press.

7. Gallagher, K. \& Myers, M. (2020). China-Latin America Finance Database. Recuperado el 1 de mayo de 2020, de The Dialogue Leadership for the Americas: https://www.thedialogue.org/map list/

8. Gil Barragán, J.M. \& Aguilera Castillo, A. (2017). China y América Latina: ¿Socios estratégicos o competidores? Negocios Internacionales (82), 73-90.

9. Hiratuka, C. (2018). Changes in the Chinese Development Strategy after the Global Crisis and its Impacts in Latin America. Revista de Economía Contemporánea, 22(1), 1-25.

10. HispanTv. (14 de August de 2017). China advierte a EEUU contra intervención en Venezuela. Recuperado el 04 de May de 2020, de https://www. hispantv.com/noticias/china/350436/venezuelaeeuu-trump-opcion-militar-injerencia

11. Index Mundi. (2019). Commodity Prices. Obtenido de https://www.indexmundi.com/commodities/

12. Jenkins, R. (2011). El efecto China en los precios de los productos básicos y en el valor de las exportaciones de América Latina. Revista de la CEPAL (103), 77-93. 
13. Johnson, K. (2017). The New Middle Kingdom China and the Early American Romance of Free Trade. Baltimore: Johns Hopkins University Press.

14. Lafargue, F. \& Lafangue, V. (2017). Objectif Concours Géographie Économique Cat A et B 2017. Paris: Hachette Educ.

15. López Villafañe, V. (2016). La emergencia del China como potencia mundial. Fin del período de alto crecimiento y nuevos desafíos. Coyuntura y debate(26), 168-196.

16. Luzuriaga, M. (2017). Inversiones China en Ecuador: Andes Petroleum y los Bloques 79 y 83. Quito: Centro de Derechos Económicos y Sociales.

17. Morrison, W. (2018). China's economic rise: history, trends, challenges, and implications for the United States. Congressional Research Service.

18. NBC News. (2017). 'America First': Read Trump's Full United Nations Speech. Obtenido de https:// www.nbcnews.com/politics/white-house/ america-first-read-trump-s-full-united-nationsspeech-n802676

19. Office of the United States Trade Representative. (13 de December de 2019). Agreement between the United States of America, the United Mexican States and Canada. Obtenido de https://ustr.gov/tradeagreements/free-trade-agreements/united-states$\underline{\text { mexico-canada-agreement/agreement-between }}$

20. Ortíz, S. (october de 2017). Inversión extranjera directa de China en América Latina y el caribe, aspectos metodológicos y tendencias durantes 20012016. Economía informa, 406, 4-17.

21. Oviedo, E.D. (2017). Inversiones de China, Corea y Japón en Argentina. Rosario: UNR Editora.

22. Perroti, D. (2015). La República Popular de China y América Latina: impacto del crecimiento económico chino en las exportaciones latinoamericanas. Revista CEPAL (116), 48-61.

23. Ray, R. \& Gallagher, K. (2015). China-Latin America Economic bulletin 2015 Edition. Global Economic
Governance Iniciative.

24. Remes Lenicov, J., Viola, A. \& Knoll, P. (2015). Las Economía de Brasil y China. Observatorio de la Economía Mundial (19), 1-16.

25. Ríos, X. (2019). El estado de las relaciones ChinaAmérica Latina. Fundación Carolina, Documentos de trabajo.

26. Rosales, O., Pérez, R., Prado, A. \& Bárcena, A. (2015). América Latina y el Caribe y China. Hacia una nueva era de cooperación económica. Santiago de Chile: CEPAL.

27. Sputnik Mundo. (21 de February de 2018). La corrupción deja pérdidas de $\$ 15.000$ millones a Venezuela. Recuperado el 02 de May de 2020, de https://mundo.sputniknews.com/americalatina/201802211076478559-caracas-casoscorruptos/

28. Tamara, G. (14 de February de 2019). Crisis en Venezuela: qué intereses tiene China en el país latinoamericano ( $y$ por qué tiene tanto que perder). Recuperado el 04 de May de 2020, de BBC News: https://www.bbc.com/mundo/noticias-america$\underline{\text { latina- } 47221713}$

29. TeleSur. (20 de March de 2020). China reitera apoyo a Venezuela ante sanciones estadounidenses. Recuperado el 03 de May de 2020, de Telesurtv. net: https://www.telesurtv.net/news/china-reiteraapoyo-venezuela-20200330-0012.html

30. The White House. (2017). National Security Strategy. Washington.

31. The World Bank. (23 de January de 2020). Commodity Markets. Recuperado el 01 de May de 2020, de Pink Sheet Data Annual prices: https:// www.worldbank.org/en/research/commoditymarkets

32. Trading Economics. (2019). Venezuela Public External Debt. Recuperado el 01 de May de 2020, de https://tradingeconomics.com/venezuela/ $\underline{\text { external-debt }}$

33. Vidal Molina, P. (2019). Neoliberalismo, 
neodesarrollismo y socialismo bolivariano. Modelos de desarrollo y políticas públicas en América Latina. Santiago de Chile: Ariadna Ediciones, 2019. Disponible en http://repositorio.uchile.cl/ handle/2250/159316

34. Vilar, J. R. (November de 2018). Auge y caída del socialismo del siglo XXI. Revista gobernanza (44).

35. Villavicencio, F. (2013). Ecuador made in China. Quiro: Interamerican institute for Democracy Fondo Editorial.

36. Xinhua. (14 de May de 2017). Full text of President $X i$ 'speech at opening of Belt and Road forum. Recuperado el 3 de May de 2020, de XinhuaNet: http://www.xinhuanet.com//english/201705/14/c_136282982.htm

37. Xinhua. (24 de November de 2016). Full text of China's Policy Paper on Latin America and the Caribbean. Recuperado el 02 de May de 2020, de http://www.china.org.cn/world/2016-11/24/ content_39777989.htm

\section{Appendixes}

Appendix 1. Chinese investments in Venezuela, millions of USD

\begin{tabular}{|c|c|c|c|}
\hline Date & Type & Lender & $\begin{array}{c}\text { Amount } \\
\text { (millions } \\
\text { USD) }\end{array}$ \\
\hline 2007 & Energy & China Developmnet Bank & 4000 \\
\hline 2009 & Energy & China Developmnet Bank & 4000 \\
\hline \hline 2009 & Mining & China Developmnet Bank & 1000 \\
\hline 2009 & Energy & China Ex-Im Bank & 500 \\
\hline 2010 & Other & CDB and Portugal's BES & 1100 \\
\hline 2010 & Energy & China Developmnet Bank & 20300 \\
\hline 2011 & Energy & China Developmnet Bank & 4000 \\
\hline 2011 & Energy & China Developmnet Bank & 4000 \\
\hline 2012 & Energy & China Developmnet Bank & 500 \\
\hline 2012 & Energy & China Developmnet Bank & 4000 \\
\hline 2013 & Energy & China Developmnet Bank & 4000 \\
\hline 2013 & Mining & China Developmnet Bank & 700 \\
\hline 2013 & Infrastructure & China Ex-Im Bank & 391 \\
\hline 2013 & Energy & China Developmnet Bank & 5000 \\
\hline 2014 & Infrastructure & China Ex-Im Bank & 4000 \\
\hline 2015 & Energy & China Developmnet Bank & 5000 \\
\hline 2016 & Energy & China Developmnet Bank & 2200 \\
\hline Total & & & $\$ 62191$ \\
\hline
\end{tabular}

Source: Gallagher \& Myers, 2020
Appendix 2. Chinese investments in Brazil, millions of USD

\begin{tabular}{|c|c|c|c|}
\hline Date & Type & Lender & $\begin{array}{c}\text { Amount } \\
\text { (millions of } \\
\text { USD) }\end{array}$ \\
\hline 2007 & Energy & China Developmnet Bank & 750 \\
\hline 2008 & Energy & China Developmnet Bank & 356 \\
\hline 2009 & Energy & China Developmnet Bank & 7000 \\
\hline 2014 & Energy & China Developmnet Bank & 3000 \\
\hline 2015 & Energy & China Developmnet Bank & 1500 \\
\hline 2015 & Infrastructure & China Developmnet Bank & 1200 \\
\hline 2015 & Energy & China Developmnet Bankk & 3500 \\
\hline 2015 & Other & China Ex-Im Bank & 1300 \\
\hline 2016 & Energy & China Developmnet Bank & 5000 \\
\hline 2017 & Other & China Ex-Im Bank & 300 \\
\hline 2017 & Energy & China Developmnet Bank & 5000 \\
\hline Total & & \multicolumn{2}{|l}{} \\
\hline
\end{tabular}

Source: Gallagher \& Myers, 2020

Appendix 3. Chinese investments in Argentina, millions of USD

\begin{tabular}{|c|c|c|c|}
\hline Date & Type & Lender & $\begin{array}{c}\text { Amount } \\
\text { (millions } \\
\text { USD) }\end{array}$ \\
\hline 2007 & Other & China Developmnet Bank & 30 \\
\hline 2010 & Other & China Developmnet Bank & 30 \\
\hline 2010 & Infrastructure & CDB and others & 10000 \\
\hline 2010 & Infraestructure & CDB and CITIC & 273 \\
\hline 2012 & Energy & China Developmnet Bank & 200 \\
\hline 2014 & Energy & China Developmnet Bank & 2500 \\
\hline 2014 & Infrastructure & Belgrano Cargas train line & 2100 \\
\hline 2014 & Other & China Ex-Im Bank & 162 \\
\hline 2017 & Other & SME development & 150 \\
\hline 2017 & Energy & China Ex-Im Bank & 331 \\
\hline 2018 & Infrastructure & China Ex-Im Bank & 1100 \\
\hline 2019 & Infraestructure & China Developmnet Bank & 236 \\
\hline Total & & & $\$ 17112$ \\
\hline
\end{tabular}

Source: Gallagher \& Myers, 2020

Appendix 4. Chinese investments in Ecuador, millions of USD

\begin{tabular}{|c|c|c|c|}
\hline Date & Type & Lender & $\begin{array}{c}\text { Amount } \\
\text { (millions of } \\
\text { USD) }\end{array}$ \\
\hline 2010 & Energy & China Ex-Im Bank & 1700 \\
\hline 2010 & Energy & China Developmnet Bank & 1000 \\
\hline 2010 & Energy & China Ex-Im Bank & 571 \\
\hline 2011 & Energy & China Developmnet Bank & 2000 \\
\hline 2012 & Other & China Developmnet Bank & 2000 \\
\hline 2013 & Infraestructure & China Ex-Im Bank & 80 \\
\hline 2013 & Energy & China Ex-Im Bank & 312 \\
\hline 2014 & Energy & China Ex-Im Bank & 509 \\
\hline 2015 & Other & China Ex-Im Bank & 5300 \\
\hline 2015 & Other & China Developmnet Bank & 1500 \\
\hline
\end{tabular}




\begin{tabular}{|c||c|c|c|}
\hline 2015 & Other & China Ex-Im Bank & 250 \\
\hline 2016 & Other & China Ex-Im Bank & 198 \\
\hline \hline 2016 & Other & China Developmnet Bank & 2000 \\
\hline 2018 & Other & China Developmnet Bank & 900 \\
\hline 2018 & Infraestructure & China Ex-Im Bank & 69 \\
\hline Total & & & $\$ 18389$ \\
\hline
\end{tabular}

Source: Gallagher \& Myers, 2020 